\title{
STAROŚĆ I MŁODOŚĆ JAKO NIEUSTANNIE AKTUALNE, UNIWERSALNE MOTYWY LITERACKIE I KULTUROWE - WPROWADZENIE DO ZBIORU STUDIÓW
}

Kategorie czy też toposy starości i młodości są bardzo często obecne we wszelkich dokonaniach będących przejawem działalności artystycznej. Funkcjonują w kulturze wysokiej, jak i popularnej, ponieważ należą do pojęć podstawowych, stanowiąc fundamentalne wymiary przebiegającej w czasie egzystencji człowieka. Będąc odbiciem ludzkiej wędrówki od początku do kresu, są etapami usytuowanymi na krańcach tej drogi, często jednak zawłaszczającymi jej cały przebieg, co wyrażają pytania o to, kiedy kończy się młodość, a zaczyna starość. Etap pośredni tej wędrówki zdaje się eliminowany. Człowiek jest albo młody, albo stary, wiek dojrzały w potocznym myśleniu traci rację bytu, przestaje być atrakcyjny, bliższy jest etapowi starości.

Starość i młodość można z sobą zestawiać, by — konfrontując je — opisać łączone z nimi cechy dystynktywne. Omawiane kategorie poddaje się także oglądowi osobno, aby też rozpatrywać każdą z nich niejako samoistnie.

Starość i młodość stały się przedmiotem namysłu i dyskursu już w antyku. Interesowali się nimi filozofowie (m.in. Marcus Tullius Cicero), jak i teoretycy literatury (np. Horatius Flaccus Quintus). Cyceron przedstawił swe poglądy w dwóch pracach: O starości i O powinnościach, natomiast Horacy w Liście do Pizonów. Dzieła te zdają się konstytuować toposy starości i młodości, funkcjonujące później w literaturze staropolskiej. Niejako wokół nich rozwinąć się miała dawna twórczość parenetyczna ${ }^{1}$, czego

\footnotetext{
* Michał Kuran — studia polonistyczne ukończył w roku 1996 na Uniwersytecie Łódzkim. Od roku 1998 pracuje w Katedrze Literatury Staropolskiej i Nauk Pomocniczych tej uczelni. Stopień doktora uzyskał w roku 2003, zaś doktora habilitowanego w 2013 roku. Od roku 2009 pełni funkcję wicedyrektora Instytutu Filologii Polskiej, należy do zespołu redakcyjnego „Czytania Literatury” i „Meluzyny”. Główne obszary zainteresowań badawczych to literatura polska XVII wieku; w szczególności literatura okolicznościowa świecka i religijna (poezja i proza), edytorstwo tekstów dawnych, epika staropolska, tematyka orientalna w literaturze staropolskiej, dorobek Samuela Twardowskiego i Marcina Paszkowskiego. Autor książek Retoryka, historia i tradycja literacka w twórczości okolicznościowej Samuela Twardowskiego (Łódź 2008) oraz Marcin Paszkowski — poeta okolicznościowy i moralista z pierwszej potowy XVII wieku (Łódź 2012), redaktor zbiorów studiów, m.in. ostatnio Wzniostość i makabra w literackich obrazach śmierci (Łódź 2014). Przygotował edycję Książe Janusz Wiśniowiecki (1598-1636) w lubelskich kazaniach pogrzebowych (Lublin 2007). Publikował artykuły w „Terminusie”, „Baroku”, „Napisie”, „Pracach Polonistycznych”, „Acta Universitatis Lodziensis - Folia Litteraria Polonica”, „Acta Universitatis Lodziensis — Folia Librorum” i w „Akapicie” oraz w monograficznych tomach zbiorowych. Recenzje ogłaszał w „Ruchu Lite-
} 
świadectwem nie tylko Żywot człowieka poczciwego Mikołaja Reja, ale także uwagi i zalecenia formułowane z myślą o wychowaniu młodego pokolenia, jakie znajdują się w traktatach i innych pismach pedagogicznych (ich autorami byli m.in. Szymon Marycjusz z Pilzna, Andrzej Gostyński, Hieronim Baliński, Erazm Gliczner). Wiedzy na temat obrazu młodości szukać można też w dziele Łukasza Górnickiego Dworzanin polski, jak też u Andrzeja Frycza Modrzewskiego w Commentariorum de Republica emendanda libri quinque. Ustanowiony w literaturze dawnej obraz pozwala dostrzec dwa fundamentalne toposy „nierozumnej młodości” i „rozumnej starości”. Naturalną cechą młodzieńca jest brak roztropności, której może nabrać w trakcie wychowania. Starzec zaś ma się legitymować mądrością. Oczywiście dopuszczalne są także dwa inne warianty: godna pochwały „rozumna młodość” (puer senex) oraz zasługująca na potępienie „nieroztropna starość”.

Warto sięgnąć po List do Pizonów Horacego, który bardzo celnie dokonał deskrypcji cech typicznych starości i młodości z myślą o literatach-dramaturgach kreujących wizerunki. Konstruując je artyści mieli korzystać z uniwersalnych modeli postaw i postępowania. Według Horacego, owa zgodność jest konieczna, by w procesie tworzenia uzyskać postać wiarygodną. Dlatego też za istotne uznał nadanie bohaterom wyrazistych cech właściwych każdemu wiekowi:

Jeżeli więc słowa nie będą zgadzać się z dolą mówiącego, rycerze rzymscy i lud wybuchną głośnym śmiechem. Wielka też różnica będzie, czy mówi [...] wiekowy starzec, czy zapalczywy młodzieniec w kwiecie wieku³.

Kontynuując rozważania, Horacy wyodrębnił cztery etapy w życiu człowieka, wśród nich młodość i starość, reprezentowane przez młodzieńca i starca, którzy legitymują się cechami ukazującymi przywileje, zalety, wady i uciążliwości wieku. Oparte na obserwacji ludzkiego życia zalecenia Horacego na temat konstruowania charakteru postaci w dramacie można rozciągnąć na całą literaturę i kulturę:

Jeżeli chcesz mieć oklaski widzów [...] to musisz poznać obyczaje każdego wieku i dać to, co przystoi latom ruchliwym i co dojrzałym. Tak dziecię, które niedawno nauczyło się mówić i pewną nogą stąpa po ziemi, pragnie bawić się z rówieśnikami, wpada bez powodu w gniew, wnet ochłonie, co godzinę jest w innym nastroju. Młodzieniec, jeszcze bez zarostu, pozbywszy się wreszcie pedagoga, cieszy się końmi i psami i trawą słonecznego Pola Marsowego, podatny jak wosk wobec kusicieli do złego, oporny wobec upomnień, powolny w przewidywaniu korzyści, rozrzuca pieniądze, wysoko patrzy, płonie namiętnością, prędki do porzucenia tego, co ukochał. [...] Wiele dolegliwości otacza starca, czy

rackim”, „Pamiętniku Literackim” i „Studiach Źródłoznawczych”. Opiekun Koła Naukowego Literatury i Kultury Staropolskiej UŁ.

${ }^{1}$ M. Pierzgalska, Toposy „mtodośc” — „starość” $w$ literaturze parenetycznej doby staropolskiej, „Acta Universitatis Lodziensis. Folia Litteraria Polonica", t. 7: 2005, s. 129-150.

${ }^{2}$ Tamże, s. 149.

${ }^{3}$ Quintus Horatius Flaccus, List do Pizonów, [w:] Rzymska krytyka i teoria literatury. Wybór, oprac. St. Stabryła, Wrocław 1983, BN II 207, s. 43-44. 
to dlatego, że ciuła, a od zbioru się biedak wstrzymuje i boi się go użyć, czy też dlatego, że wszystko w ogóle trwożliwie i zimno załatwia, wszystko odkłada na później, żywiąc dalekie nadzieje; gnuśny, żądny przyszłości, trudny w pożyciu, skłonny do narzekań, chwalca dawnych czasów, w których sam jeszcze był chłopcem, karciciel i surowy sędzia młodych. Przychodzące lata przynoszą z sobą wiele dobrego, odchodzące zabierają wiele ${ }^{4}$.

Obraz nakreślony przez Horacego jest odzwierciedleniem rzeczywistości (mimesis) i konwencji literackiej (imitatio), zarazem wyłaniają się z niego cechy stereotypowe postaci młodzieńców i starców. Twórcy dawnych epok również starali się naśladować realny bieg zdarzeń, co znajduje odzwierciedlenie w pamiętnikach, eposach, poematach dydaktycznych i kazaniach pogrzebowych. Wielką pochwałą było powiedzieć o człowieku zmarłym w średnim wieku, że już osiągnął pełnię życia za sprawą doświadczenia, mądrości, zwłaszcza cnoty, dlatego też zmarł nie doczekawszy starości w sensie biologicznym.

Twórcy pragnęli też na rzeczywistość wpływać, jak choćby Rej w Żywocie człowieka poczciwego, kreśląc obraz modelowego dzieciństwa i wzorcowej młodości (księga 1) oraz pogodnej starości (księga 3). W księdze I (kapitulum 3), uczył rozpoznawać typy charakterów dziecka, by potem dawać szczegółowe rady wychowawcze, na przykład, jak ubierać, karmić, przed czym chronić, czego uczyć dziewczynki a czego chłopców:

[...] albowiem wierz mi, iż młode wychowanie roztropne siła potym obyczajów dobrych na starość każdemu umnożyć może. A widamy to i miedzy rodzoną bracią, iż jeden, doma źle a swowolnie wychowany, jaki jest brzydki w obyczajoch swoich, jako jest niedbały w sprawach swoich, iż wszystko snadniej i utracić, i sam się w niwecz obrócić może. A drugi będzie dobrego a poczciwego wychowania, wszystko ono, za nim chodząc, pozbiera 5 .

Pisarz podkreślał rolę otoczenia w kształtowaniu obyczajów, doceniał dydaktyczną siłę lektury, która podsuwa godne naśladowania wzorce osobowe. Nauka winna służyć cnocie: m.in. „sprawiedliwości, stałości, roztropności, pomierności, miłosierdziu, sta-

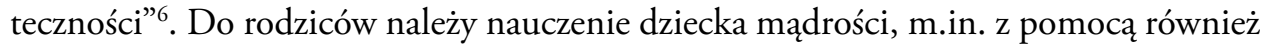
pożytecznych rozmów, by umiało przez dalsze lata korzystać rozsądnie z życia.

Rej przestrzegał starców przed pokusą nieograniczonego korzystania z życia, przypominając o rychłym zgonie i o konieczności podporządkowania poczynań doczesnych potrzebom życia po śmierci:

Panie stary,

Porzuć czary,

Im sie wiary,

Gotuj mary,

Bo bez wiary

\footnotetext{
${ }^{4}$ Tamże, s. $47-48$.

${ }_{5}^{5}$ M. Rej, Żywot człowieka poczciwego, [w:] tenże, Wybór pism, oprac. A. Kochan, Wrocław 2006, BN I 308, s. 376.

${ }^{6}$ Tamże, s. 387.
} 
Diabeł szary

Do swej fary

Za swe dary

W swe browary

Na przewary [warzenie piwa]

Nie wziął cię na święta.

Mądrze gól! [postępuj mądrze] ${ }^{7}$.

Stwierdził Rej, że w starości człowiek powinien się trzymać cnoty, unikać szaleństwa. Przypomniał o eschatologicznym wymiarze życia ludzkiego, o nieodwracalnym upływie czasu, wzywał, by podtrzymywać gotowość do ostatniej drogi. Zalecał, by nie lamentować nad tym, co bezpowrotnie przeminęło. Za nieszczęsnych uznał tych, którzy swoje lata poświęcili próżnowaniu, przypominał o strachu człowieka starego przed śmiercią. Rozważaniom starca o śmierci towarzyszyć miały zajęcia, które mogły dawać pociechę, jak korzystanie z ciepła domowego zapewnianego przez sam budynek, przytulnego łóżka, usłużności otoczenia. Satysfakcję dawać miało dobrze prowadzone gospodarstwo, radzenie sobie z przeciwnościami losu.

Z kolei obraz konfrontacji starości i młodości znajdujemy w Transakcyi wojny chocimskiej Wacława Potockiego. Waloryzowana dodatnio (w duchu laudatio personae) postać starego statecznego, doświadczonego, pełnego mądrości rozwagi, postępującego honorowo, uczciwie, zgodnie z nakazami religii hetmana wielkiego litewskiego

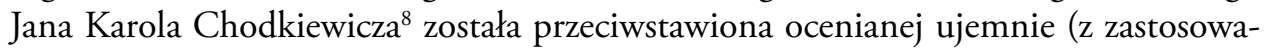
niem repertuaru środków retorycznych właściwych w ramach genus demonstrativum naganie - vituperatio) postaci młodego sułtana Osmana II, który był m.in. porywczy, zapalczywy, niecierpliwy, okrutny, wierzył wróżbitom - a więc nie posiadał stabilnych poglądów religijnych, prowadził walkę niehonorowo. Osmana cechować miały także nienawiść, zapalczywość i brak namysłu. Wizerunki nakreślone przez Potockiego utrwalały stereotypowe cechy przypisywane młodym i starym.

Pozbawiony jednoznaczności obraz tak młodości, jak i starości nakreślił Krzysztof Opaliński w satyrze Na złe ćwiczenie i rozpasana edukacyja młodzi. Pozornie zdawać by się mogło, że jest ona utworem dydaktycznym, którego cel stanowi ukazanie ne-

\footnotetext{
${ }^{7}$ Tamże, s. 447. Podane w nawiasach objaśnienia przywołuje się za tą samą edycją.

${ }^{8}$ Wizerunek Chodkiewicza-starca w kaznodziejstwie pogrzebowym zrekonstruowałem w studium Jan Karol Chodkiewicz - przykład wizerunku starca w oracjach pogrzebowych, [w:] Dojrzewanie do petni życia. Starośc w literaturze polskiej i obcej, red. S. Kruk, E. Flis-Czerniak, Lublin 2006, s. 125-146. W tym samym tomie Tadeusz Piersiak opublikował studium zestawiające obraz Chodkiewicza i Stanisława Lubomirskiego w Wojnie chocimskiej Wacława Potockiego. Przywołany tom gromadzi liczne prace poświęcone starości. Wśród nich znajdują się też studia, których autorzy zestawiają bądź konfrontują literackie obrazy starości i młodości, jak czynią Renarda Ocieczek, Piotr Pirecki i Monika Metlerska. Autor wstępu do tomu, Stefan Kruk, odnotował, iż Miesięcznik „Więź” „poświęcił osobny zeszyt antagonizmowi Starzy i młodzi (1968, nr 1)" - (Wprowadzenie, [w:] Dojrzewanie do petni życia, s. 23), jak też wspomniał opublikowany w 1995 roku zbiór Starość. Wybór materiatów... opracowany przez środowisko literaturoznawców z Uniwersytetu Śląskiego (Aleksander Nawarecki i Adam Dziadek) z częścią czwartą poświęconą relacji „Stary z młodym”.
} 
gatywnych cech uczącej się młodzieży szlacheckiej. W istocie krytyka magnackiego satyryka równie mocno dotyka także osób reprezentujących starsze pokolenie - rodziców uczących się dzieci. Zwracając się do szlachcica, który zachłannie gromadził dobra materialne, krzywdził też innych, by przekazać je niegodnemu posiadania ich potomkowi, poeta bowiem stwierdził:

Nie umiecie ćwiczenia dawać dziatkom z młodu.

Owszem, przykładem swoim barzi ich psujecie?

Nakreśliwszy obraz pozornego wykształcenia, szkodliwej swobody, która umożliwiała hojne korzystanie z rozrywek w miejscach gromadzących swawolącą młodzież w kraju, jak i zagranicą, ostrze krytyki skierował satyryk w stronę ojców. Ramię w ramię z synami wiedli oni życie godne ukazania jako antywzór. Szlachecki dom, podobnie jak miasto, stał się miejscem dalszej deprawacji:

[...] Cóż wżdy po nim w domu,

Kędy się nie nauczy, chyba wszeteczeństwa

I wszelkich niepoczciwych obyczajów oraz.

Pan ociec sam stanie mu za mistrza dobrego,

Pań matka też i siostry takiegoż gatunku.

Pije ociec w dzień i w noc, nie wyda go synek,

Gra kostek - i tych pewnie ten dopomoże.

Zwadźca on, wprawi się też niedługo w toż i syn.

Rad podwiczki pilnuje, i w tym go wyrazi

Ad amussim, i w inszych zbytkach i nierządzie,

I które tylko możesz ogarnąć rozumem

Niecnotach; ojcowski dom stanie mu za szkołę ${ }^{10}$.

Dostrzegł satyryk i kazał uznać za konieczność zachowanie dystansu wobec dziecka, jak też przyjęcie roli surowego opiekuna, który będzie wymagał od potomka tego, do czego sam się nie przekonał. Satyryk wzywał więc pośrednio rodziców, którzy nie nabyli mądrości, mającej zgodnie z modelem kulturowym stanowić cechę przedstawicieli starszego pokolenia, by zmienili własne postępowanie, jak też zachęcał wprost do wzorcowego wypełniania obowiązków wynikających z wieku:

Utraty i złych rzeczy nie ucz, owszem broń;

Niech się też synek z tobą nie pospolituje,

Aby cię i na potym szanował, i matkę,

Niech zna oko surowe ojcowskie i matki.

[...]

Bo takiego potrzeba przybrać [preceptora — dop. M. K.], kto by umiał

Kierować nim i jego porywczą młodością ${ }^{11}$.

\footnotetext{
${ }^{9}$ K. Opaliński, Na złe ćwieczenie i rozpasana edukacyją młodzi, [w:] tenże, Satyry, oprac. L. Eustachiewicz, Wrocław 2005, według pierwodruku z 1953 roku (BN I 147), s. 7, w. 12-13.

${ }^{10}$ Tamże, s. 10, w. 62-73.

${ }^{11}$ Tamże, s. 14, w. 169-170.
} 
Powraca więc przekonanie, że młodość to okres rozwoju wybujałego temperamentu, który należy kiełznać. Obowiązek ten spoczywa na szlacheckich rodzicach, do których należy nie tylko dawanie przykładu, ale też zatrudnienie odpowiedniego preceptora mającego sprawować bezpośrednią pieczę nad młodym pokoleniem.

Opaliński więc wzywał w satyrze inicjującej zbiór do zachowania tradycyjnych ról przez osoby starsze, rodziców. Próby porzucenia oczekiwanej postawy kończyć się miały anarchią i utratą pozycji społecznej, na jaką zapracowały pokolenia. Misja dobrego wychowania młodych spoczywała na ich rodzicach, którym zabraniał satyryk bratania się z dziećmi i wspólnego oddawania się przyjemnościom.

Dziedzictwo kultury dawnej, w tym utrwalony w niej obraz młodości i starości, najlepiej oddaje mądrość przekazana w przysłowiach. Znane i cenione w antyku, spopularyzowane przez Erazma z Rotterdamu w słynnych Adagiach zyskały dużą popularność $\mathrm{w}$ odnowionej formie $\mathrm{w}$ dobie renesansu. Znamy je też bezpośrednio z kart dopełniającego Żywot Ezopa Fryga z 1622 roku Biernata z Lublina zbioru bajek, w których paremia odgrywają niepoślednią rolę. O wartości przysłów przekonani byli też gromadzący je Mikołaj Rej, Salomon Rysiński, Grzegorz Knapiusz, Wacław Potocki, Stanisław Herakliusz Lubomirski oraz Andrzej Maksymilian Fredro, jak również znacznie późniejsi Samuel Adalberg oraz Julian Krzyżanowski i jego zespół.

Przysłowia o młodości i starości obrazują relacje między kobietą i mężczyzną („Gdyby starzy nie igrali, skądże by się młodzi brali?”, „Z młodym stara — śmieszna para; stary z młodą grozi szkodą”, „Daremne zachody staremu do młodej”, „Staremu różaniec, młodemu dziewczyna”, „Staremu stara, młodemu młoda, zaś drwa ogniowi, ryba wodzie - nic zgodliwszego”, „Staremu za piecem zagrodzić, młodemu do dziewczyny chodzić”, „Lepiej być kochaną przez starego, niż zwodzoną przez młodego”, „Gdzie się młodzi kochają, niech się starzy nie wdają”, „Lepiej za starego cesarza, niż za młodego pisarza”), mówią o wartości rozumu i mądrości („Nierychło na starość rozumu się uczyć”, „Jak starzy śpiewają, tak młodzi skaczą”, „Dwie rzeczy nie do rzeczy: młodego o radę pytać, a starego o krótką odpowiedź”, „Stary niech radzi, a młody niech słucha”, „Młodego rada a starego wojna — śmiechowisko”), pokazują konflikt pokoleń i różnice między starością a młodością („Kto chce być długo starym, niech nie będzie długo młodym”, „Lepiej starego dźwigać, niż młodego ścigać”, „Lepiej za starym nosić niż młodego prosić”, „Lepiej u starego pod brodą, niż u młodego pod kijem”, „Starego pomiataja, gdy młodzi nastają”, „Starego szpeci, co dobre dla dzieci”, „Staremu szata, młodemu lata”, „Stary płacze, młody skacze”, „Młodzi skwapliwością grzeszą, starzy więcej czasem się lękają, niż trzeba”, „Młodzi w głowie muchy mają, prędko starszych oszukają"), ale też potrafią pozytywnie waloryzować starość, doceniając wartość doświadczenia („Żywot starszego uczy młodszego”, „Stary, a młodego mógłby przeskoczyć”, „Stary, ale jary”, „Gdzie młody nie doskoczy, tam stary dolezie”, 
„Niejeden młody zedrze zęby, niż stary z nóg się zwali”), negatywnie opisują myślenie i zarozumiałość młodych lub starych („Stary do rady, młody do zwady”, „Młody, a stare dzieje pamięta”, „Więcej czasem znajdzie u młodego rozumu w pięcie, niż u drugiego starego w mózgu”, „Żeby młodzi tak zrobili, jako starzy uradzili”), opisują upływ czasu i przemianę, jakiej doświadcza nieuchronnie człowiek, choć wolałby pozostać wiecznie młody, dlatego też stara się zachować pozostałości tego, co przeminęło („Stary płacze po młodości, młody wzdycha do starości”, „Starzy sobie lat ujmują, młodzi przydają”, „Stary łacno odmłodnieje, gdy sobie trochę poleje”, „Kto starał się za młodu być starym, ten na starość zawsze będzie młodym”, „Kto się z młodu nie wyszaleje, musi na starość”, „Gdzie młody wystąpi, tam szaleje stary”, „Młody gorący, a stary zimny”, „Młody może umrzeć, a stary musi”), pokazują konsekwencje złego lub dobrego postępowania w młodości na starość („A cóż na starość, kiedy tak za młodu?”, „Biedna starości, wszyscy cię żądamy, a kiedy przyjdziesz, to zaś narzekamy”, „Poznać łatwo w starości, jaki kto był w młodości”, „Co za młodu zaniedbasz, to ci się na starość wróci”, „Coś siał w młodości, to będziesz zbierał w starości”, „Czego się człowiek za młodu nauczy, to na starość znajdzie”, „Czegoś z młodu nie upiekł, nie będziesz jadł starym”, „Jeżeli w czas nie złomiesz młodości, wierz mi, iże zapłaczesz nad nią ku starości”, „Każdy na starość żałuje, że się z młodu nie uczy»”, „Kto nie pracuje za młodu, ten na starość dozna głodu”, „Młody nabywaj, stary zażywaj”, „Kto za młodu hula, skacze, ten na starość za to płacze"), opisują swoistość starości i młodości („Starość nie radość”, „Młodego człowieka krasa zdobi, a starego szaty”, „Młodemu praca, staremu lata ciężą”, „Młodemu świat się śmieje, staremu płacze”, „Staremu wino mlekiem, młodemu miodem”, „Z starym pieszczota, z młodym robota”, „Sława młodego z czerstwości, starego z pieniędzy, śrzedniego z dzielności zaleca”, „Młodym robić, mężom rządzić, starym modlić się przystoi”) i relacje między starością a młodością — podobieństwa, różnice i wzajemne powinności („Jak się stary ustroi, za młodego ostoi”, „Stary ze starym, młody z młodym rad przebywa”, „Stary rychlej młodemu wybaczy”, „Nie wyrozumie młody staremu, aż dozna”, „Młody starszego ma szanować, starszy młodego zaś miłować”, „Młody, ale by starego nauczył”) ${ }^{12}$.

Przykłady zestawiania starości z młodością i młodości ze starością przynosi także sztuka. Przykładowo tematyką tą interesowali się Teodor Axentowicz (1859-1938), malarz portrecista, rysownik i grafik, autor m.in. prac: Starzec i dziewczyna (ok. 1900), Lirnik i dziewczyna (ok. 1900), kilku obrazów zatytułowanych Starość i młodość (m.in. prace z lat 1927, 1937), Mtodość i starość, Jesień, starosśc i mtodość, też utrwalający wizerunki dzieci (np. Portret dziewczynek), młodych kobiet (np. Dziewczyna z różami, Dziewczyna zdzbanem, Wiosna) oraz starców (np. Wizja, Weteran, Stary Hucul). Twórca nie malował jednak ani młodych mężczyzn (poza autoportretem), ani starych ko-

\footnotetext{
${ }^{12}$ Nowa ksiegga przystów i wyrażeń przystowiowych polskich, oprac. w oparciu o dzieło Samuela Adalberga Zespół Redakcyjny pod kier. J. Krzyżanowskiego, Warszawa, t. 2 - 1970, t. 3 - 1972. Wszystkie przysłowia cytuje się za hasłami „Młodość” i „Młody” — t. 2, s. 498-507 oraz „Starość” i „Stary” — t. 3, s. 306-317. Nie podaje się źródeł, z których zostały zaczerpnięte przysłowia, nie sytuuje się ich w czasie.
} 
biet. Starość kojarzył ze starcem-mężczyzną, młodość z dziewczynką, młodą kobietą ${ }^{13}$. Podobnie tematyką młodości i starości zajmował się Wlastimil Hofman (1881-1970), przedstawiciel symbolizmu, uczeń i przyjaciel Jacka Malczewskiego. Portretował dzieci, starców, jak też malował sceny ukazujące baśniowy świat faunów. Do jego prac należą m.in. Portret starca (1921), Starzec, (1923), Starość i mtodość (1925), Starość (1918), Starzec i dziewczyna (1922 i z lat 20.), Dwaj chtopcy z glinianym ptaszkiem ${ }^{14}$. $\mathrm{O}$ ile w jego malarstwie znajdujemy portrety chłopców, o tyle nie utrwalał wizerunków starych kobiet. Starość i młodość stały się tematem prac portretującego górali i góralki Stanisława Górskiego, a także Brunona Schulza (Kobieta i pochylony starzec), Ludomira Śledzińskiego (Gtowa staruszki) i Jerzego Dudy-Gracza.

Wydaje się, że utrwalony w literaturze i kulturze w postaci toposów, jak i przysłów oraz $\mathrm{w}$ malarstwie obraz cech kojarzonych z młodością i starością od antyku po dzień dzisiejszy, pod wpływem postępujących zmian kulturowych i obyczajowych uległ w ostatnich czasach fundamentalnym zmianom. Symptomy tych przemian polegających na przejmowaniu inicjatywy obyczajowej i kulturotwórczej przez młode pokolenie, jak i dążenie starszego pokolenia do poniechania roli przypisanej osobom starszym dostrzegał już Opaliński w Satyrach. Znaczącego osłabienia doznał autorytet starszego pokolenia dopiero jednak całkiem niedawno. Obecnie w zasadzie mądrość życiową, jaką zdobyli ludzie starsi, mogą oni wykorzystywać na własne potrzeby. Młodzież dorastająca w fundamentalnie odmiennych warunkach ustrojowych, obyczajowych, technologicznych częściowo też kulturowych, nie chce słuchać rad starszych. Czerpie wiedzę o życiu od rówieśników, z Internetu, opiera się wreszcie na własnych doświadczeniach. Osłabło znaczenie przewodników, do których należą rodzice i dziadkowie, szkoła i związki wyznaniowe. Kierunek, można powiedzieć, uległ odwróceniu. To młodzi uczą starszych korzystania z nowinek technicznych, często też wyznaczają standardy obyczajowe i etyczne, uczą mobilności, gotowości zaczynania życia od nowa. Młodzi własnym przykładem zachęcają starszych nie tylko do większej swobody, ale też przekonują do troski o los zwierząt, szczepią świadomość ekologiczną, dają przykład otwartości na ludzi z innych kręgów kulturowych, do czego przyczyniają się podróże i emigracja. Nie obserwuje się już wzmożonej walki starych z młodymi, odwieczny konflikt pokoleń zdaje się zamierać. Starsze pokolenie albo milcząco nie akceptuje zaszłych zmian, albo poddało się dynamicznemu rozwojowi wydarzeń rozumiejąc, że uwidaczniającym się tendencjom, logicznie biorąc, trudno stawiać opór.

Tak więc zmagania młodych ze starymi i starych z młodymi, jakie opisuje literatura XIX i XX wieku również tracą na aktualności. Rewolucja, którą postulowano w tych dziełach, dokonała się. Opisy starcia międzypokoleniowego, walki z konwenansami

\footnotetext{
${ }^{13}$ Zob. Wybór prac artysty dostępny na Teodor Axentowicz [online], dostęp 26 sierpnia 2015, dostępny: $<$ http://www.pinakoteka.zascianek.pl/Axentowicz/Index.htm>; Archive Art Database [online], dostęp 26 sierpnia 2015, dostępny: < http://www.agra-auctions.com/gallery.php?off=108\&curr=PLN\&sch=1\&or$\mathrm{d}=\mathrm{da} \& \mathrm{~s}=1 \& \mathrm{gal}=1 \& \mathrm{id} \_m a l a r z a=13 \& i n t=>$. Zbiór gromadzi reprodukcje 110 prac Axentowicza.

${ }^{14}$ Vlastimil Hofman [online], dostęp 26 sierpnia 2015, dostępny: <http://www.agra-auctions.com/gallery. php?off=96\&curr=PLN\&sch=1\&ord=cu\&s=1\&gal=1\&id_malarza=107\&int=>.
} 
mają już tylko walor historyczny. Obecnie zainteresowanie mogą budzić przede wszystkim utrwalone w tych utworach obrazy dojrzewania i inicjacji, ujmujące finezją opisu, wprowadzające na wyższe piętra doznań, ukazujące trudno uchwytne niuanse. Zastanawiające, że deskrypcje inicjacji znajdujemy w poezji i prozie kobiecej. To dziewczęta i kobiety chcą być stale młode, kochane, poznawać świat, brać udział w wydarzeniach, co widać szczególnie mocno w literaturze, począwszy od XIX wieku (w obecnym tomie czytamy o tym w omówieniach twórczości m.in. Eugenii Żmijewskiej, Zofii Nałkowskiej, Marii Krüger i Haliny Snopkiewicz). Mężczyźni zaś kultywują starość, chcą osiągnąć ją jak najszybciej, by zyskać autorytet i szacunek, pragną dojrzeć przedwcześnie, nie zakosztowawszy smaków młodości (w obecnym tomie myślenie to ujawniono w twórczości Jana Lechonia i Tadeusza Konwickiego).

Przesunięciu uległy też granice wieku. Skoro Dante w Boskiej Komedii uznał, że połową egzystencji, zgodnie również z myśleniem zapisanym w Biblii, jest 35 rok życia, przyjmując, że granicą wieku ma być 70 lat (tak właśnie Księga Psalmów, Ps. 90, 10), to za absolutną młodość uznać by należało okres do 20, najdalej 25 roku życia, zaś starość to czas po 50 roku życia. Obecnie granice te zdają się przebiegać inaczej. Do 35 roku życia ludzie uważają się absolutnie za młodych, zaś po osiągnięciu 60 lat można mówić o wczesnej starości.

Rozpatrywane razem i osobno w kontekście zwłaszcza literatury od dawnej po najnowszą kategorie starości i młodości stały się atrakcyjnym tematem rozważań konferencyjnych. Zaprosili do nich studenci i doktoranci należący do Koła Naukowego Literatury i Kultury Staropolskiej, działającego pod moją opieką przy Katedrze Literatury Staropolskiej i Nauk Pomocniczych UŁ. W skład grupy, która postanowiła zorganizować studencko-doktorancką konferencję naukową, weszli mgr Paulina Poterała, lic. Klaudia Adamczewska, mgr Joanna Woron-Trojanowska, mgr Katarzyna Ossowska, mgr Beata Prokopczyk, mgr Justyna Muszyńska i lic. Alicja Okólska. Sprawność organizacyjną na etapie przygotowań zapewniły: mgr Poterała, która prowadziła korespondencję z uczestnikami, przygotowywała zaproszenie, opracowała konferencyjny harmonogram i książkę abstraktów, prowadziła obrady, wreszcie gromadziła napływające teksty. Z kolei mgr Woron-Trojanowska zatroszczyła się o przygotowanie strony internetowej, multimedialnej prezentacji towarzyszącej obradom i materiałów informacyjnych, brała udział w otwieraniu konferencji oraz prowadziła obrady. O promocję wydarzenia zadbała mgr Ossowska, która pozyskała też patronat Plastra Łódzkiego, ELDEZET.PL oraz płyń POD PRĄD. Z kolei mgr Prokopczyk i Muszyńska opracowały wizytówki, doglądały też recepcji. W pracy administracyjnej uczestniczyła z kolei aktywnie lic. Adamczewska, która prowadziła zestawienia, jak też wspomagała mgr Poterałę.

W zaproszeniu zaproponowaliśmy uczestnikom, by podjęli rozważania wokół następujących problemów: 
- miłość młodzieńcza, miłość na starość;

- poszukiwanie drogi życia, podróż;

- mądrość i doświadczenie;

- bunt i rewolucja;

- głupota i bezmyślność;

- choroby ciała i duszy;

- dorastanie i dojrzewanie;

- rozrachunek z życiem;

- czas i przemijanie;

- wspomnienia i marzenia.

Nadesłane zgłoszenia pozwoliły wykrystalizować się nieco innym kręgom tematycznym, którym postanowiliśmy przypisać problematykę wystąpień, jak: Spojrzenia w przeszłość; Narodziny i śmierć; Młodość i starość kobiety; Rozmyślania o życiu i śmierci; Wokót starości; Smaki mtodości i starości; Twórczość pod koniec życia; Czy wiek ma znaczenie? Z uwagi na wymogi logistyczne nie zawsze możliwe było ścisłe dostosowanie tematów wystąpień do głównego zagadnienia patronującego danej sekcji.

W trwających trzy dni obradach (23-25 maja 2014 roku), które odbywały się w Centrum Szkoleniowo-Konferencyjnym UŁ przy ul. Kopcińskiego w Łodzi, wzięło udział 36 referentów, reprezentujących poza UŁ (17 referatów) sześć uczelni krajowych (UMK w Toruniu, UP w Krakowie, UJ, UW, UG, KUL, URz i UJK w Kielcach) i jedną zagraniczną (Uniwersytet Ostrawski). Przeważali doktoranci, ale występowali także absolwenci studiów licencjackich przygotowujący podczas kolejnego etapu kształcenia prace magisterskie, ponadto dwoje doktorów. Obrady miały charakter interdyscyplinarny. Obok polonistów występowali filozofowie, socjolożka/polonistka zajmująca się filmem, referentka badająca funkcjonowanie fotografii w kulturze oraz badacz zajmujący się piosenką.

Oto wykaz referatów w kolejności zapisanej w programie konferencyjnego spotkania:

1) dr Monika Urbańska (UŁ) Patrzę na zniszczenie, co święci swe dzieło, lecz przecież nic w mym sercu nie poszło na marne — retrospekcje Jana Lechonia.

2) mgr Dawid Nowakowski (UŁ) Vetus melius est. Zarzuty nowinkarstwa i apologia tradycji w szesnastowiecznych sporach między humanistami a scholastykami.

3) mgr Stanislava Schupplerová (Uniwersytet Ostrawski) Pamięć i region literacki.

4) mgr Joanna Jabłońska (URz) „Czemu młodości nie dał mi Bóg, tej płochej, lekkiej, swawolnej?”- rozrachunek z życiem w twórczości Marii Bartusówny.

5) mgr Katarzyna Stępińska (UG) Dziecko w twórczości księdza Jana Twardowskiego.

6) Klaudia Adamczewska (UŁ) Niezawodny przepis na zdrowa starość - profilaktyka i lecznictwo w "Zielniku” Stefana Falimirza.

7) mgr Monika Bednarczyk (UP) Droga krzyżowa jako metafora przemijania.

8) mgr Paulina Poterała (UŁ) „Odstapcie, nie umarła dzieweczka, ale śpi”- życie jest czekaniem na śmierć — z kaznodziejstwa Fabiana Birkowskiego. 
9) mgr Aldona Jankowska (UŁ) Odkryć piękno w starości, czyli o życiu kobiety dojrzakej w świetle wybranych czasopism przetomu XIX i XX wieku.

10) Sylwia Kępa (UP) Obraz pensjonarki w literaturze trywialnej początku XX wieku (na podstawie powieśsi „Ptomyk. Z pamiętnika instytutki” Eugenii Żmijewskiej).

11) Anna Kaźmierska (UŁ) Kobieta u progu życia. Dojrzewanie do mitości, seksualności, przyjaźni w „Kobietach” Zofii Natkowskiej.

12) Kamila Kulesza (UŁ) „Gdy wspomne, w onej szczesnej dobie czym byłam, a czym dziś się stałam". Antropologiczno-historyczna analiza motywu mtodości i starości w poezji Françoisa Villona.

13) Katarzyna Bis (UP) Bunt czy egzaltacja? Obraz mtodości w literaturze popularnej na przyktadzie wybranych powieści dla dziewczat z okresu PRL-u.

14) Ewa Joanna Marczak (UG) „Żyje się tylko chwilę” - czy Halina Poświatowska zmarta bardzo mtodo?

15) mgr Terezie Foldynová (Uniwersytet Ostrawski) Pohyb a jeho tvoŕivá sila v „Sestře" Jáchyma Topola.

16) Daria Płaneta (UP) Wiosna i jesień życia w kulturze. Potyczki z czasem w poezji różnych epok.

17) mgr Emila Kolinko (UW) Dziennik choroby Eleonory Woronieckiej na tle dziewiętnastowiecznej diarystyki.

18) mgr Marta Tyszko (UJ) Dlaczego „człowiek wolny o niczym nie myśli mniej niż o śmierci"?

19) dr Małgorzata Herchel Jezykowo-kulturowy obraz czasu oparty na metaforyce cyklu dobowego i rocznego utrwalony w inskrypcjach nagrobnych cmentarzy wiejskich (na przyktadzie wybranych wsi Podkarpacia i Małopolski).

20) mgr Dominika Dźwinel (UMK) Pomiędzy odą a sielanką. Wizje starości w twórczości Adama Naruszewicza.

21) mgr Kamil Dźwinel (UMK) W mtodości bytem Tezeuszem". Perspektywa senilna w twórczości Jacka Kaczmarskiego.

22) Katarzyna Ossowska (UŁ) Starość, czyli „niemożność, zdezaktualizowanie, zblaknięcie", jako leitmotiv $w$ tryptyku sylwicznym oraz autokomentarzach Tadeusza Konwickiego.

23) mgr Jowita Podwysocka-Modrzejewska (UŁ) Élan vital w poezji Bostawa Leśmiana - sita sprawcza (nie) tylko mtodości.

24) Anna Wiśniewska-Grabarczyk (UŁ) Pamięćsmaku — czy literatura potrafi „mówić kulinariami"? Na przykładzie kategorii starości i mtodości.

25) mgr Ewelina Warumzer (UJ) Mitość w mtodości czy na starość? Obraz relacji międzyludzkich $w$ kinie.

26) mgr Bartłomiej Łuczak (UMK) Nie tylko muzyczna droga wirtuoza. O mtodości, dorastaniu i klęsce życiowej Romualda z „Książki pamiątek” Narcyzy Żmichowskiej.

27) mgr Joanna Woron-Trojanowska (UŁ) Młodzi kochankowie i ich rodzice w polskich romansach barokowych. Kształtowanie relacji. 
28) dr Assel Baieli (KUL) Motywy starości i mlodości w powieści Hanny Malewskiej pt. „Panowie Leszczyńscy”.

29) mgr Magdalena Ciechańska (UŁ) Jak dojrzewata stowiańska opowieść Juliusza Stowackiego? Od „Balladyny”, przez „Lille Wenedę”, do „Króla-Ducha”.

30) mgr Mateusz Grabowski (UŁ) „Ogień i piasek” — o ostatnim okresie życia i twórczości Norwida na podstawie elegii "Na zgon Poezji”.

31) mgr Elwira Kamola (UG) Żyt tak jak pisat i pisat tak jak żyt — wizja przemijania w tomiku Jerzego Harasymowicza "Ma się pod jesieñ”.

32) mgr Ewelina Szymczak (UJK) Ja już nie ten... - motyw przemijania i starości w wybranych utworach Franciszka Karpinskiego.

33) mgr Aleksandra Smusz (URz) Wariacje na temat starości w opowiadaniach Brunona Schulza.

34) mgr Michał Sadowski (UŁ) Pierzchliwi, mtodzi, ptosi - wizerunki zbtakanych postaci w „Nadobnej Paskwalinie” Samuela Twardowskiego ze Skrzypny w kontekście mitologii $i$ innych dziet literackich.

35) mgr Beata Prokopczyk (UŁ) Umizgi staruszka — o sielance "Chloe i Likas" Franciszka Zabtockiego.

36) mgr Justyna Muszyńska (UŁ) Czy wiek ma tu jakieś znaczenie? Stary i młody $w$ „Dies irae” Lucjana Rydla.

Rzecz jasna, zestawienie to nie jest zbieżne w 100\% z wykazem tekstów, które ostatecznie znalazły się w tomie. Niektórzy referenci nie dosłali swoich prac, rezygnując z publikacji, nieliczne studia odrzucili recenzenci. Ostatecznie w skład tomu weszło 27 tekstów.

Z uwagi na swoistość monograficznego tomu, który w naturalny sposób różni się od konwencji i dynamiki, jakim podporządkowane są obrady konferencyjne, wprowadziłem nieco inny podział materiału badawczego niż wynika to z proponowanej tematyki czy też delimitacji narzuconej przez rytm spotkania na żywo. Wchodzące w skład tomu prace postanowiłem pogrupować wokół czterech kategorii. Pierwsza z nich obejmuje teksty łączące lub konfrontujące z sobą obie kategorie, zarazem ukazujące je z zastosowaniem szczególnego rodzaju klucza badawczego, który wykracza poza granice czystego literaturoznawstwa (W kręu antropologii i filozofii). Grupa druga gromadzi prace odwołujące się do kategorii młodości. Znalazły się w niej wypowiedzi na temat dzieciństwa, jak też inicjacji. Cztery z sześciu studiów podejmują rozważania skoncentrowane wokół problematyki kobiecej (Niewinność i kosztowanie smaków młodości). Trzecia grupa, najliczniejsza, odnosi się do kategorii starości. Studia przybliżają zmagania zz nią poetów, począwszy od Mikołaja Reja, poprzez Franciszka Zabłockiego, Franciszka Karpińskiego, Juliusza Słowackiego i Cypriana Kamila Norwida, po Jana Lechonia i Jacka Kaczmarskiego. Prace przybliżają również wizje Stefana Falimirza, Marii Bartusówny, Brunona Schulza i Tadeusza Konwickiego (Odcienie i smaki starości). Ostatnia grupa studiów dotyczy tego, co może towarzyszyć starości, 
ale też stanowi jej nieubłaganą konsekwencję (Cierpienie i śmierc). Teksty ukazują, że cierpienie i śmierć dotykają nie tylko ludzi starych, lecz także dzieci, młodych, czy będących w kwiecie wieku. Prace sygnalizują nieuchronność przemijania, ujawniają zarazem ludzkie pragnienie pozostania w pamięci potomnych. Studia obejmują także problematykę przygotowania się do śmierci.

W tomie znajdujemy charakterystyki utworów respektujących poetyki kolejnych okresów literackich od średniowiecza po czasy współczesne. Omawiane dzieła literackie przynależą do poezji oraz do prozy, reprezentując liczne gatunki i formy, jak: poemat, traktat, kazanie, poradnik, wierszowaną epikę, sielankę, dramat, elegię, epitafium, powieść, krótkie utwory liryczne (wiersze), rozważania drogi krzyżowej, reportaż aż po piosenkę. Mamy tu struktury literackie należące do literatury wysokiej, jak i użytkowej.

Zgromadzone w tomie prace obejmują głównie twórczość autorów polskich, nieliczne wyjątki wykraczają poza ten krag. Młodzi badacze spojrzeli przekrojowo na literaturę od średniowiecza po współczesność. Cenne jest nawiązanie do sporów, jakie elektryzowały europejskich uczonych doby wczesnego renesansu, jak też rozważania o poezji Françoisa Villona. Dość liczne są prace z zakresu literatury dawnej, renesansowej, barokowej i oświeceniowej. Odwołują się do twórczości Stefana Falimirza, Mikołaja Reja, Fabiana Birkowskiego, coraz silniej zyskującego na znaczeniu Samuela Twardowskiego, modnego Klemensa Bolesławiusza, Franciszka Zabłockiego i Franciszka Karpińskiego. Zainteresowaniem młodych badaczy cieszy się nadal literatura romantyczna w postaci dokonań Juliusza Słowackiego i Cypriana Kamila Norwida, jak też epigonki Marii Bartusówny. Literatura pozytywizmu znalazła odbicie w tomie w znikomym stopniu. Obecna jest prekursorka feminizmu, Narcyza Żmichowska. Najbardziej przyciąga jednak pisarstwo autorów XX-wiecznych zarówno tych, którzy apogeum twórczości osiagnę̨li przed wojną, jak i po niej. Badacze pisali o dokonaniach żyjącej na przełomie wieków Eugenii Żmijewskiej, Brunona Schulza, Jana Lechonia, Zofii Nałkowskiej, Haliny Poświatowskiej, Tadeusza Konwickiego, tekściarza i muzyka Jacka Kaczmarskiego, reportażysty Wojciecha Tochmana. Sięgnięto także do prozy socrealistycznej, jak również do twórczości użytkowej w postaci współczesnych rozważań służących odprawianiu nabożeństwa drogi krzyżowej oraz napisów nagrobnych $\mathrm{z}$ terenu Małopolski i Podkarpacia.

Zwrócić należy uwagę na duże zainteresowanie pisarstwem kobiecym z jego nierzadkim ukierunkowaniem ku dyskursowi feministycznemu. Pojawiły się bowiem prace na temat życia i twórczości Żmijewskiej, Żmichowskiej, Bartusówny, Nałkowskiej i Poświatowskiej, literatury dla dziewcząt. Analizuje się także obraz kobiet w prozie i poezji męskiej.

Wątkami interesującymi, które przewijają się w pracach, są inicjacja — w tym także seksualna, jak i zderzenie pragnień erotycznych starców z oczekiwaniami dziewcząt. Podejmując te tematy autorzy odzwierciedlali problemy rzeczywistości, zmagając się stale z obyczajowym tabu. Ukazywali, że upływ czasu jednym pozwala zyskać fizyczną 
atrakcyjność, wejş́ w świat cielesnych doznań, innym zaś odbiera możliwość aktywności w przestrzeni erotycznej, pozbawiając bezpowrotnie walorów i atutów, zsyłając w niebyt. Owo zderzenie starości szukającej za wszelką cenę zaspokojenia w kontakcie fizycznym z młodością ukazane zostało w poezji oświeceniowej. Starzec staje się pośmiewiskiem, gdy zamiast czcić mądrość i budować swój autorytet ugania się za pannami, które stanowczo odrzucają jego awanse, pragnąc zainteresowania młodszych. Zarazem badacze ukazywali kobiety poszukujące miłości i spełnienia fizycznego, poznające własną cielesność i seksualność. To bohaterki utworów Twardowskiego, Żmijewskiej, Nałkowskiej, jak też powieści dla dziewcząt wczesnego PRL-u. Ogląd zmagań kobiety z życiem dają prace na tematu Bartusówny i Poświatowskiej.

Obraz starości konstytuują w tomie zwłaszcza studia o poezji Lechonia oraz prozy Schulza i Konwickiego. Nie jest to starość łatwa, pozbawiona problemów i modelowa. Badacze odtwarzają trudne zmagania z tym okresem, utrwalone na kartach dzieł literackich, brak zgody na starzenie się, bezczynność, niemożność odnalezienia własnego miejsca w świecie. Przeciwieństwo tego obrazu kreślą prace o wizji szczęśliwej starości u Falimirza i Reja, jak też w wybranych utworach ukazujących kobiety z XIX i XX wieku.

Nie tylko starość wiedzie ku śmierci. Choroba i cierpienie, często też właśnie śmierć dotykają ludzi w różnym wieku. Nieodwołalność wyroku i nieodwracalność stanu, jak też konieczność przygotowania się na to, co po życiu — dokumentują teksty o twórczości z kręgu religijnego Birkowskiego i Bolesławiusza, jak też rozważania drogi krzyżowej. Dramaty umierających oddają zapisy wyryte na płytach nagrobnych. To religia uświadamiać ma ludziom zarówno nieuchronność przemijalności, jak i budzić nadzieję na życie po śmierci oraz do niego przygotować. Teksty pokazują, że cierpienie i śmierć, mogące towarzyszyć zarówno staremu, jak i młodemu są powodem walki człowieka, który pragnie się od nich uwolnić, szukając ucieczki czy to w kosztowanie smaków życia, czy to w niebędącą synonimem rezygnacji lub kapitulacji refleksję przygotowującą do nieuchronnego kresu.

Jako opiekun Koła Literatury i Kultury Staropolskiej UŁ i redaktor niniejszego tomu pragnę podziękować w pierwszym rzędzie najpierw autorom, którzy zechcieli odpowiedzieć pozytywnie na wystosowane przez Koło zaproszenie konferencyjne. Szczególnie mam na myśli tych, którzy nie poprzestali na wygłoszeniu swoich referatów, ale odważyli się zmierzyć z przygotowaniem publikacji, poświęcić czas na dopracowanie tekstów. Słowa podziękowania kieruję do prodziekan Wydziału Filologicznego oraz kierownika Katedry Literatury Staropolskiej i Nauk Pomocniczych dr hab. prof. UŁ Krystyny Płachcińskiej, która nie tylko obrady otwierała, lecz także w ich części uczestniczyła, słuchając wystąpień referentów. Dziękuję też współpracownikom z Koła Naukowego najpierw za zgłoszenie inicjatywy konferencji i za czas oraz pracę poświęconą przygotowaniu spotkania. Szczególne wyrazy wdzięczności należą się mgr Joannie Woron-Trojanowskiej, jak i mgr Paulinie Poterale, które wzięły na siebie główny ciężar prac przygotowawczych. Dzielnie wspierała je p. Klaudia Adamczewska. Za 
przygotowanie i opiekę nad recepcją oraz nad uczestnikami obrad dziękuję mgr Justynie Muszyńskiej i mgr Beacie Prokopczyk. Całemu Zespołowi za stworzenie bardzo przyjaznej atmosfery podczas konferencji.

Dziękuję również Recenzentom, którzy zgodzili się podjąć oceny nadesłanych prac, a więc prof. dr hab. Marioli Jarczykowej, kwalifikującej teksty należące do literatury dawniejszej, prof. dr hab. Tadeuszowi Błażejewskiemu, który recenzował prace należące do literatury współczesnej, jak też dr hab. Annie Car, badającej współczesną literaturę czeską. Dzięki wnikliwej lekturze Recenzentów udało się wyeliminować prace niegodne druku, zaś pozostałym nadać doskonalszy kształt.

Michał Kuran

\title{
SENILITY AND YOUTH AS STILL ACTUAL, VERSATILE LITERARY AND CULTURAL MOTIFS - AN INTRODUCTION TO THE COLLECTION OF STUDIES
}

\section{Summary}

The study presents selected examples of functioning in the literature and culture the category of senility and youth in the idea of Antiquity, as well as examples from the circle of literature of Renaissance and Baroque (in the context especially of Parenetics). The versatility of these categories present also proverbs existing in such works of culture as Erazm of Rotterdam's Adagia and Ezop's fables. The examples of meetings, but also confrontations, and well as independent functioning motifs of senility and youth in the art are among others paintings of Teodor Axentowicz and Wlastimil Hofman. The study also pays attention to the transformations, which have occurred in the functioning of senility and youth in the culture of recent years, including changes in defining their borders. Deliberations present afterwards course of conference devoted to the titled issue and also they describe motifs, which have guided to group studies collected in the volume.

Słowa kluczowe: starość i młodość — konferencja naukowa — parenetyka — paremiografia Keywords: senility and youth — scientific conference — Parenetics — Paremiography

Translate by Ewa Maciejczyk

Szczególne podziękowania za opiekę, wszechstronną pomoc oraz poświęcony czas i energię należą się opiekunowi Koła Literatury i Kultury Staropolskiej, Panu dr hab. Michałowi Kuranowi.

\author{
Paulina, Michał, Klaudia, \\ Katarzyna, Anna, \\ Beata i Justyna
}

